\title{
Investment, Saving and Stagnation from a Keynesian Perspective
}

\begin{abstract}
It can also be shown from a Keynesian perspective that planned investment and saving are diverging in the twenty-first century and that there is a risk of sustained (secular) underemployment unless appropriate countermeasures are taken by the state. In this chapter, we look at the arguments that Keynesian authors have used, in both older and more recent writings, to demonstrate the possibility of secular stagnation and at the possibilities they considered for overcoming tendencies toward stagnation. We make clear that, despite general differences in the theoretical framework and some differences in detail, there are a number of parallels between the Keynesian view and the new capitaltheoretical conception presented in this book. This applies both for the causes of the structural divergence between planned private saving and private investment and for its consequences.
\end{abstract}

\subsection{The Disparity Between Capital Supply and Capital Demand and the Divergence Between Saving and Investment}

In the previous chapters of this book, we have argued that long-term structural factors are responsible for the fact that the supply of private capital and the demand for private capital are not in equilibrium at a non-negative interest rate and full employment. Under the conditions in question, in our view, private capital supply is greater than private capital demand. In particular, the trend toward significantly higher life expectancy is, on the one hand, increasing the population's desire to save, whereas, on the other hand, due to a number of factors, private demand for capital is not increasing relative to national product or total consumption. In other words, the argument of this book is that under the given circumstances, the natural 
interest rate mechanism is no longer able to bring saving and investment into an equilibrium that is compatible with prosperity. Our approach thus forms part of the neoclassical tradition, in which the interest rate is of central importance for capital supply and demand. Since John Maynard Keynes, however, there are also other views on the mechanisms that bring investment and saving into equilibrium and on the conditions that have to be fulfilled to eliminate macroeconomic imbalances and to achieve full employment. Nonetheless, it can also be argued from a Keynesian perspective that investment and saving are diverging in the twenty-first century and that there is a risk of sustained underemployment and stagnation unless appropriate countermeasures are taken by the state. In this chapter, we will look at the arguments used by some Keynesian authors, in both older and more recent writings, to demonstrate the possibility of secular stagnation and at the measures they recommend for preventing tendencies toward stagnation from being realized. Despite the different theoretical approach, we will see that both the finding of a divergence between saving and investment and the analysis of its consequences exhibit important similarities to the arguments developed in this book.

\subsection{Public and Private Saving and Public and Private Investment in a Macroeconomic Context}

We have essentially worked with stock variables in our analysis up to now. Stocks have a definite relationship to flows, which will be our focus in what follows. Households that would like to accumulate wealth can only succeed in doing so, if a portion of their income is not spent for consumption purposes, but rather saved. ${ }^{1}$ Overall, firms have to invest more than is required just to replace plant and equipment in order to increase their capital stock: i.e., they have to undertake net investment (in what follows, simply "investment" for short). Saving and investment are flows, which affect the stock of household wealth and capital stock, respectively.

On the macrolevel, the equality of saving and investment is a key equilibrium condition. To show this, we start from the national income equation:

$$
Y^{d}=C_{P}+C_{G}+I_{P}+I_{G}+(E X-I M)
$$

$Y^{d}$ : aggregate demand; $C_{P}$ : private consumption; $C_{G}$ : public (or "government") consumption; $I_{P}$ : private investment; $I_{G}$ : public (or "government") investment; $E X$ : exports; IM: imports.

In equilibrium, aggregate demand $Y^{d}$ on the goods market is equal to aggregate supply $Y^{s}$. For national income $Y, Y^{d}=Y^{s}=Y$ holds in equilibrium. Equilibrium national income is thus determined by:

\footnotetext{
${ }^{1} \mathrm{We}$ abstract here from changes in stocks due to changes in valuation.
} 


$$
Y=C_{P}+C_{G}+I_{P}+I_{G}+(E X-I M)
$$

In Sect. 3.11, we were able to show that the OECD plus China region has a nearly balanced current account vis-à-vis the rest of the world $(E X=I M)$. If, moreover, we define national saving as the part of national income $Y$ that is not used up by private consumption $C_{P}$ or public consumption $C_{G}$, i.e.,

$$
S=Y-C_{P}-C_{G}
$$

then Eq. 7.2 gets reduced to the well-known identity of aggregate saving and aggregate investment:

$$
S=I
$$

When this equilibrium condition is satisfied, then supply and demand are in equilibrium on the goods market. We now divide saving, just like investment, into private and public saving. In equilibrium, then,

$$
S_{P}+S_{G}=I_{P}+I_{G}
$$

holds. Household saving consists of the part of current income that households do not consume. The taxes that private individuals pay to the state have to be subtracted from income $Y$, and the subsidies that private individuals receive from the state have to be added to it. If we designate net taxes (taxes minus transfer payments) as $\tilde{T}$, then the following holds for private saving $S_{P}$ :

$$
S_{P}=Y-\tilde{T}-C_{P}
$$

Public saving $S_{G}$ is equivalent to the sum of the state's net acquisition of financial and non-financial assets. The state's net acquisition of financial assets equals the difference between its revenues $\tilde{T}$ and its expenditure $G=C_{G}+I_{G}$. Its net acquisition of non-financial assets is equal to its net investment $I_{G}$. Public saving is thus the sum of the budgetary surplus or deficit and public investment:

$$
S_{G}=(\tilde{T}-G)+I_{G}
$$

As discussed at length above, in the OECD plus China region, on the one hand, especially due to rising life expectancy, households increasingly want to accumulate wealth, but, on the other, private demand for capital is hardly increasing relative to the national product. Consequently, private saving $S_{P}$ is persistently and increasingly greater than the more slowly growing private investment $I_{P}$ :

$$
S_{P}>I_{P}
$$

This is what we call the "Great Divergence." 
We have argued, furthermore, that the endogenous process of adjustment via the real interest rate, which could restore the balance between saving and investment, does not work under the specific conditions of the twenty-first century. In order to restore equilibrium, such that there can be prosperity with full employment and price stability, the state has to take measures to ensure that a substantial-and, given the continuing rise in life expectancy, growing - part of the desired saving of private individuals can be realized. This can be seen by inserting Eq. 7.7 into Eq. 7.5 and then rearranging:

$$
I_{P}-S_{P}=(\tilde{T}-G)
$$

This presentation in terms of flow variables is the counterpart to the presentation in terms of stock variables that, for theoretical reasons, we have preferred in this book: $Z-T=D$. Equation 7.8 makes clear that the difference between current private investment and current private saving can be made up in the current period by commensurate net borrowing by the state. If private saving and private investment come to diverge again, the budgetary deficit in the subsequent equilibrium becomes greater. Public debt increases accordingly.

A permanent budgetary deficit thus becomes a conditio sine qua non for sustained prosperity. We argue that it is only thanks to such a deficit that the equality of saving and investment can be restored without bringing about undesirable economic consequences. But the restoration of equilibrium without adverse consequences requires the relevant political institutions to intervene in the economy. The willingness to offset a gap between planned investment and planned saving by net borrowing (expressed as a flow) or corresponding public debt (expressed as a stock) thus becomes an indispensable condition for economic stability.

\subsection{The Adjustment Mechanism in Disequilibrium}

The equilibrium condition $S=I$ is derived from the well-known definitional relationships of national accounting and it is always satisfied ex post. Ex ante, however, it is possible for this condition not to be met. In this case, there is no equilibrium on the goods market and no equality between aggregate voluntary saving $S^{v}$ and aggregate investment $I^{v}$. Instead, $S^{v} \neq I^{v}$ holds. Theories are then needed to explain how an economy that has fallen into disequilibrium can return to equilibrium. The different paradigms in economic theory provide different explanations. Both between and within the various macrotheoretical paradigms, the following questions are given sometimes very different answers.

1. What long-term factors lead to a situation in which $S^{v} \neq I^{v}$ ?

2. What happens when $S^{v} \neq I^{v}$ ?

3. Is government intervention necessary, useful or harmful when $S^{v} \neq I^{v}$ ?

4. If the government should intervene, in what way should it do so and using what instruments? 
Our aim in the following is to show how our finding in this book that $S^{v} \neq I^{v}$ and its possible consequences appear from the perspective of Keynesian theory.

In considering the relationship between saving and investment, the natural rate of interest has been our main focus thus far. In our approach, the interest rate is key, because both the levels of (private) investment and that of (private) saving are dependent upon the interest rate $(r): S_{P}(r), I_{P}(r)$. We have argued that under the different conditions that prevailed in earlier times, a sufficiently flexible interest rate could bring investment and saving into equilibrium.

A further distinguishing feature of our reflections up to this point was that saving and investment are to some extent in a hierarchical relationship to one another. Given a certain interest rate level, the preferences of households for more or less current consumption as compared to future consumption are decisive for the supply of capital (in the form of savings). ${ }^{2}$ The interest rate mechanism then ensures that investment adjusts in such a way that saving and investment are brought into equilibrium in the long run and there is prosperity (full employment). The level of saving thus "determines" the level of investment. We could also describe this figuratively and in highly simplified fashion as follows: Saving and investment are in equilibrium in the same car and are thus moving at the same speed - but saving is in the driver's seat. ${ }^{3}$

Since Keynes, however, there is also an entirely different view of the relationship between saving and investment. In Keynes too- but for entirely different reasonsplanned investment and planned saving do not come into balance. For Keynes, the interest rate does not, in general, have the function of harmonizing saving and investment that it is assigned in neoclassical economics. In the Keynesian system, the failed coordination of saving and investment is at the origin of the employment problem of a monetary economy. The second important difference concerns the direction of causality in the relationship between investment and saving. Like Marx and Schumpeter, Keynes was of the opinion that it is not saving that dominate investment, but, on the contrary (innovation or profit-driven) investment that plays the key role and the level of saving adapts to the latter: "But we have shown that the extent of effective saving is necessarily determined by the scale of investment..." (Keynes 1936, p. 375).

In Keynes, this is due to the fact that in a monetary economy, the banking system can, as it were, create money or credit "out of thin air" (fiat money). This creates the additional liquidity required for financing investment without there having first to

\footnotetext{
${ }^{2}$ In an economic model in which only goods are exchanged and there is no money, investment necessarily presupposes a foregoing of goods and hence of consumption in the present. In Wicksell (1936 [1898]), a kind of intertemporal lending of goods take place. The real interest rate is understood as the relative price of a homogeneous good in the future and in the present. For Wicksell, the real interest rate is determined by the time preference of consumers.

${ }^{3}$ This is not to deny that the interest rate simultaneously affects both investment and saving in neoclassical theory. But at least for full employment equilibrium, James Meade's famous metaphor of the dog wagging its tail applies: "...a dog called savings wag[s] his tail labelled investment" (Meade 1975, p. 62).
} 
be an equivalent foregoing of consumption (= saving). ${ }^{4}$ The fact that in Keynes, investment and saving are not, in principle, brought into equilibrium by the interest rate mechanism, as in neoclassical theory, is important to keep in mind. Keynes developed a theory of a monetary economy in which the interest rate is determined on the money market, which Keynes explained by his theory of liquidity preference. ${ }^{5}$ Instead, the adjusting of saving and investment to one another comes about by way of the level of production, since saving is dependent on income. Apart from the prevailing monetary interest rate, the profit expectations that entrepreneurs connect to a planned investment are a key factor for determining the level of investment in turn. These expectations can be extremely volatile, however. They can easily change and, with them, so too does investment demand. It is thus highly uncertain whether aggregate investment is enough to create sufficient effective demand to bring about full employment. For Keynes, a situation in which planned full-employment saving and planned investment are equal was not fundamentally inconceivable, but it was not assured. Hence, the analysis of a situation in which ex ante saving and investment are unequal, i.e., $S^{v} \neq I^{v}$, was highly relevant for him.

The path to an equilibrium of saving and investment - which Keynes, however, only analyzed using a comparative static approach-principally takes place, as already discussed, via a change in aggregate income that brings saving and investment into equilibrium ex post. The adjustment takes place, above all, by way of the income multiplier. ${ }^{6}$ If consumer demand is lacking, for example, more will be saved at a given income, whereby the additional saving can also trigger interest rate cuts. In Keynes, however, this path does not necessarily lead to the restoration of an equilibrium between saving and investment with full employment. On the one hand, the profit expectations of entrepreneurs can become so troubled in this sort of situation that, despite lower interest rates, investment falls instead of rises. The consequence is a further decline in income, consumption, investment and hence, ultimately, also saving. On the other hand, the interest rate can be at its lower limit (in a "liquidity trap"), since there is speculation on falling prices on the bonds

\footnotetext{
${ }^{4}$ Citing criticism of the treatment of financial resources as loanable funds, Bofinger and Ries (2017) critically examine recent theories of stagnation in which the natural rate of interest plays an important role. They emphasize that private saving is not a precondition for investment in a monetary economy and hence reject the savings glut approach for fundamental theoretical reasons. Palley (2019), for whom a shortage of demand likewise cannot chiefly be eliminated by interest rate changes, makes a similar argument. But such criticism ignores the fact that the high propensity to save is the result of an active desire to accumulate wealth and not a "passive" reaction to insufficient effective demand.

${ }^{5}$ The interest rate in Keynes and the natural rate of interest that is our focus are thus based on entirely different conceptions. In the General Theory, Keynes distanced himself from Wicksell's natural rate of interest, which he had previously used: "If there is any such rate of interest, which is unique and significant, it must be the rate which we might term the neutral rate of interest..." (Keynes 1936, p. 243; emphasis in the original). This rate must be "consistent with full employment" and is in this sense an "optimum rate," as Keynes also called it (ibid.).

${ }^{6}$ In Keynes, the process of adjustment of demand and supply in disequilibrium is generally characterized by quantities reacting faster than prices. Nonetheless, price adjustments also play a role in Keynes.
} 
market. In this case, the additional savings are hoarded and no cut in the interest rate takes place. ${ }^{7}$ Here too, the adjustment takes place via a decline in production and falling income.

Precisely on the question of whether saving tends to dominate investment or vice versa, Keynesian theory clearly differs from neoclassical theory. Keynes puts the focus on the autonomous investment decisions of entrepreneurs. In analytical terms, investment is there "first" and aggregate saving adjusts to the latter. Saving is determined by income and income is determined by investment, such that ultimately saving is dependent on investment. To return to the image we used previously: In the Keynesian paradigm, entrepreneurs are in the driver's seat thanks to their autonomous investment decisions, whereas savers become passengers in the same car.

In the following, we want to examine to what extent the analysis of (dis)equilibrium between saving and investment on Keynesian premises differs from the basic approach of this book. We will see that - even though the direction of causality between saving and investment is viewed precisely the other way around - the situational analysis and, above all, the economic policy prescriptions exhibit a very large overlap with what we have argued thus far.

In Keynes and the Keynesian economists who have followed him-first and foremost, Alvin Hansen - the inability of an economic system to reach a level of production at which sustained full employment prevails is explained, above all, by a permanent insufficiency of (effective) demand. An economy that is characterized by such an insufficiency is in a situation of stagnation or, from a long-term perspective, in a state of secular stagnation. ${ }^{8}$

\subsection{John Maynard Keynes as Spiritual Father of the Modern Theory of Stagnation}

Though often regarded as a pure analyst of the short term, Keynes dealt with questions of the long-term evolution of the economy at many places in his work. In Keynes's view, this long-term evolution is characterized by tendencies toward stagnation. This is why Joseph A. Schumpeter described Keynes as the spiritual father of the modern theory of stagnation in his History of Economic Analysis: "Keynes must be credited or debited, as the case may be, with the fatherhood of modern stagnationism" (Schumpeter 1954, p. 1172).

\footnotetext{
${ }^{7}$ There is talk is of a "zero lower bound" in the current discussion about possibilities of stimulating demand by means of an expansionary monetary policy, since, in practice, the nominal central bank rate cannot be reduced (much) below zero. The zero lower bound plays an important role in the argumentation of some current stagnation theories: for example, in Summers (2014); cf. Sect. 7.5. ${ }^{8}$ Keynes and Hansen were by no means the first economic theorists to regard stagnation as possible. The major representatives of classical political economy already discussed the causes and consequences of stagnation. For contemporary overviews of the historical precedents in economic theory, cf. Anselmann (2020, pp. 25-149).
} 
Keynes was firmly convinced that highly developed economies would sooner or later encounter a problem with full employment and prosperity, since they would one day have exhausted all their profitable investment potential:

[S]ooner or later, we shall be faced, if not with saturation of investment, at any rate with increasing difficulties in finding satisfactory outlets for new investment. (Keynes 1943, p. 360)

One of Keynes's most important works in which he takes a very long-term perspective is his essay on "The Long-Term Problem of Full Employment" (Keynes 1943). Here, Keynes elaborated a forecast of future economic development, which he divided into three phases. Whereas the first phase is characterized by full employment, inflationary pressures and greater investment than saving, the second phase would be distinguished by investment and saving being more or less equal while preserving full employment. After this Golden Age, however, Keynes expected a phase of stagnation on the demand side, since the demand for capital goods would at some point be saturated and hence planned investment would be less than full-employment saving. As a solution, Keynes recommended economic policy measures that make saving less attractive and stimulate household consumption.

Keynes provided the theoretical grounds for his expectation of stagnation in his General Theory of Employment, Interest and Money (Keynes 1936). In Chap. 21, he listed the factors that he believed were responsible for investment being great enough to keep employment at a high level during the nineteenth century:

During the nineteenth century, the growth of population and of invention, the opening-up of new lands, the state of confidence and the frequency of war over the average of (say) each decade seem to have been sufficient, taken in conjunction with the propensity to consume, to establish a schedule of the marginal efficiency of capital which allowed a reasonably satisfactory average level of employment to be compatible with a rate of interest high enough to be psychologically acceptable to wealth-owners. (Keynes 1936, p. 307)

This period, Keynes continues, is about to come to an end, and he also did not expect any such favorable conditions for economic development to prevail in the future:

To-day and presumably for the future the schedule of the marginal efficiency of capital is, for a variety of reasons, much lower than it was in the nineteenth century. ${ }^{9}$ (Keynes 1936, p. 308)

\footnotetext{
${ }^{9}$ It is understandable, in light of these remarks, why Schumpeter saw the origin of the modern theory of stagnation in Keynes's work. On the above-cited passage from the General Theory, Schumpeter (1954, p. 501) writes verbatim: "Here, then, we have the origin of the modern stagnation thesis." But Schumpeter finds that the basic idea of Keynes's stagnation theory was already present in Keynes (1919) The Economic Consequences of the Peace (Anselmann 2020, p. 44).
} 
Keynes thus expressed his doubts that the favorable economic conditions that he identified for the nineteenth century would continue to exert their influence. At the same time, this allows us to deduce what Keynes regarded as the crucial determinants of long-term economic development (Kurz 2017, p. 121):

1. Firstly, he assumed that, due to a fundamental psychological law, saving rises disproportionately as compared to income, which brings about a decline in consumer demand. This argument exhibits certain parallels to classical underconsumption theories.

2. Keynes was convinced that "the demand for capital is strictly limited" (Keynes 1936, p. 375). Hence, he expected that the possibilities of profitable investment would diminish in the long term, resulting in a tendency for the marginal efficiency of capital to decline. ${ }^{10}$ Here, Keynes's argument is similar to those of Smith, Marx, Walras and other theorists of stagnation before him, who, for various reasons, assumed a long-term fall in the profit rate.

3. Finally, there is his view on the function of the interest rate that has already been mentioned above. Keynes argues that the interest rate reacts either not at all or at least not enough to the oversupply of private savings.

All this contributes to the fact that there is insufficient effective demand, resulting in a long-term weakening of growth. Elsewhere, Keynes listed other factors that also point in the direction of tendencies toward stagnation. He was concerned, in particular, about the expected decline in population growth (Keynes 1937). In his view, positive growth in population is a highly significant stimulus for capital investment, since population growth raises business expectations and directly increases demand: above all, for buildings and capital goods like plant and equipment. Thus, in various places, Keynes made clear that in his opinion, investment would grow more or less at the same pace as the population. $\mathrm{He}$ assumed, however, that population growth could come to a standstill and finally even become negative: resulting, on the one hand, in a decline in investment demand and, on the other, in a rise in the propensity to save due to an increase in average incomes and the decline in the size of families (Keynes 1937, p. 15). ${ }^{11}$ Moreover, the nature of future technological change would also have a negative impact on demand for investment goods. Keynes expected, namely, that technological change would be capital-saving, which would lower the capital-output ratio

\footnotetext{
${ }^{10} \mathrm{He}$ even considered the possibility that a situation could arise in which, little by little, no more net investment would be undertaken, leading growth in the aggregate capital stock to come to a complete standstill (Keynes 1936, pp. 323-324).

${ }^{11}$ For a number of reasons, however, it is questionable whether fewer persons per household really does increase the propensity to save. In equipping themselves with certain consumer goods, larger households benefit from economies of scale, which, other things being equal, results in lower consumption per capita. If demographic change is responsible for the decreasing household size, then one should consider that in old-age savings are normally used up.
} 
and also, for this reason, weaken investment demand in the long run. ${ }^{12}$ In the end, Keynes argued, insufficient effective demand for investment and consumer goods will lead to a contraction of production, which would come to be below the full-employment level.

If we consider Keynes's overall expectations for the long-term tendencies of developed economies, falling into stagnation appears unavoidable for him. According to Keynes, a downward spiral can lead to the establishing of a new equilibrium of saving and investment at a level of production at which there is no full employment. In his view, this level of production can persist over a long period of time. Even if Keynes did not use the expression "secular stagnation," his description of this condition is very close to what will later be the usual definition of the term:

In particular, it is an outstanding characteristic of the economic system in which we live that, whilst it is subject to severe fluctuations in respect of output and employment, it is not violently unstable. Indeed it seems capable of remaining in a chronic condition of sub-normal activity for a considerable period without any marked tendency either towards recovery or towards complete collapse. (Keynes 1936, p. 249)

Since, according to Keynes, there is no endogenous mechanism that restores full-employment equilibrium, government intervention via monetary and/or fiscal policy is required. Since monetary policy quickly comes up against its limits here, essentially just fiscal measures are available. At most, the stabilization of entrepreneurs' investment expectations or - as a last resort-public steering of investment could represent other appropriate responses in Keynes's view (Keynes 1936, p. 378).

Supposing that it is possible to solve the problem of employment in a stagnating economy (for example, by reducing labor time), Keynes-like, for example, John Stuart Mill-by no means regarded stagnation as a threat. In his essay on "Economic Possibilities for Our Grandchildren” (Keynes 1930), in particular, he gave expression to the idea that a highly developed economy that is no longer growing could be seen as one that has solved humanity's economic problem. In such a society, it would be possible to live a comfortable life and work only a few hours per week, for example. Despite this optimistic assessment, Keynes repeatedly pointed out the risks for prosperity and employment that are inherent to the expected tendencies toward stagnation. He took the view, however, that it is possible actively to counter these tendencies. To this extent, Keynes was not a stagnation pessimist like Marx, for example, who regarded the decline into stagnation and, ultimately, the collapse of the capitalist economic system as inevitable.

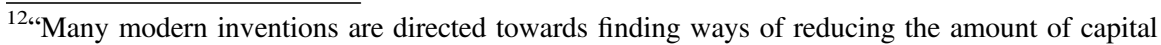
investment necessary to produce a given result..." Drawing on Böhm-Bawerk's terminology, Keynes continues, "I do not believe, therefore, that we can rely on current changes of technique being of the kind which tend of themselves to increase materially the average period of production" (Keynes 1937, p. 14).
} 
Keynes's views on the long-term perspectives of economic development had a strong influence on Alvin H. Hansen. Hansen was described by Samuelson (1976, p. 25) as "the American Keynes." In the 1940s, he made what was undoubtedly the most important contribution to the development of the modern theory of stagnation. In his "rediscovery" of the problem of stagnation in 2013, Larry Summers explicitly referred to Alvin Hansen, who, like Summers today, once taught at Harvard University. It will come as no surprise, then, that Hansen's theory of stagnation, which we will examine in the next section, exhibits strong similarities to Keynes's reflections.

\subsection{Alvin Hansen and Secular Stagnation}

Alvin H. Hansen was initially very skeptical about Keynes's new economic thinking and only became a Keynesian in the later part of his academic career (Samuelson 1976, p. 25). ${ }^{13}$ In a 1936 review of Keynes's General Theory, Hansen (1936) still had a very reserved reaction to Keynes's claim that he had developed a new general economic theory. But a few years later, his attitude to Keynes's main work had fundamentally changed. In order to contribute to the dissemination of Keynesian ideas, he even wrote a popular introduction to Keynes for economics students (Hansen 1953).

It was Alvin Hansen who introduced the term "secular stagnation" into the literature. He made clear what he meant by it when he wrote:

This is the essence of secular stagnation - sick recoveries which die in their infancy and depressions which feed on themselves and leave a hard and seemingly immovable core of unemployment. (Hansen 1939, p. 4)

The secular stagnation hypothesis is clearly based on the same theoretical principles as Keynes's analysis of equilibrium with underemployment. According to Hansen, the key problem is

... a lack of planned investment as compared to desired saving at the full-employment level of output. (Hansen 1966, p. 7)

Unlike in the approach of the present book, for Hansen, the decisive trigger for the diverging of planned saving and planned investment is not an increased propensity to save or, in other words, a growing desire to accumulate wealth on the part of households. For Hansen, the primary cause for the appearance of tendencies to stagnation is rather the deficient investment demand of firms. Constant or growing savings volume, but lack of investment opportunities are key features of what he called a mature "high-savings economy" (Hansen 1941, pp. 306-309).

\footnotetext{
${ }^{13}$ It would be reductive to classify the later Hansen as exclusively Keynesian. Institutional arrangements also play an important role in his analysis (Hansen 1941). Hence, Backhouse (2019, p. 454) rightly characterizes Hansen as "...a blend of Keynesian economics with American Institutionalism.”
} 
This interpretation is supported by the observation that Hansen discussed the possible causes of reduced investment at length, but only went into the determinants of saving more or less in passing. One hardly finds any remarks in Hansen on why the problem of a growing divergence between saving and investment could be exacerbated precisely by more saving. The main focus of his interest was clearly a lack of investment demand:

For it is an indisputable fact that the prevailing economic system has never been able to reach reasonably full employment or the attainment of its currently realizable real income without making large investment expenditures. (Hansen 1939, p. 5)

Why did Hansen expect there to be a lack of profitable investment opportunities in the future? This becomes clear, when we recall what are, in his view, the key determinants of investment demand. He mentions: (1) The availability and discovery of new land and new resources, (2) population growth and (3) technical progress.

For Hansen, all three determinants are exogenous variables and they are necessary stimuli for investment demand. Given the economic and social developments that Hansen expected in the USA, he was skeptical, however, about the preconditions for the continued force of these factors. In light of the nearly complete settlement of the USA, the impetus that long came from expansion onto new land was going gradually to peter out. ${ }^{14}$ Population growth rates would not always be able to remain as high as they were at the time when the USA was the most important magnet for immigration in the world. As regards technical progress, Hansen noted that its rate is negatively affected by the decline of the first two factors. He concluded that there is hence a risk of investment activity weakening in the long run. Consequently, Hansen spoke of a coming "period of investment stagnation" (Hansen 1939, p. 5). It can thus be seen that for Alvin Hansen, secular stagnation is primarily caused by a stagnation of investment. ${ }^{15}$

In his 1939 presidential address to the American Economic Association, in which he focused on the future growth prospects of the US economy in light of an expected weakening of population growth, Alvin Hansen also referred to the traditional idea that the economic system could come back into a full-employment equilibrium thanks to an endogenously triggered reduction in the interest rate. $\mathrm{He}$ explicitly mentioned Wicksell and Wicksell's analysis of the interest rate and the rate of profit, but he expressed strong skepticism about the interest rate being able to fulfill the function Wicksell assigns to it in light of the future evolution of the US economy (Hansen 1939, p. 5). Hansen was convinced rather that too much significance had hitherto been attached to the interest rate as a determinant of

\footnotetext{
${ }^{14}$ In this connection, Hansen often spoke of the closing of the "American frontier" (Hansen 1939, p. 9) or of the "western frontier" (Hansen 1941, p. 44). His recommendation to develop a "new economic frontier" was later frequently taken up by other authors as well (Backhouse 2019, p. 453).

${ }^{15}$ “"The Hansen-Keynes version holds that stagnation is the result of a declining rate of return on investment" (Blaug 1962, p. 152).
} 
investment, and he thus made clear that he intended to follow the new Keynesian point of view:

Yet all in all, I venture to assert that the role of the rate of interest as a determinant of investment has occupied a place larger than it deserves in our thinking. (Hansen 1939, p. 5)

The only possible replacement that Hansen saw for the diminishing force of the extensive factors, land and population, was a substantial, but targeted, expansion of debt-financed public investment. He was very skeptical about the possibilities of an expansionary monetary policy. For Hansen, debt-financed public investment was thus the first choice: also because Hansen believed there were narrow limits both to what higher taxation could accomplish and — unlike Keynes - to the possibilities of income redistribution in a free market system. ${ }^{16}$

Hansen's address also includes a remark on the consequences of an aging population. It makes clear that Hansen considered private household demand as significant too, but that he connected this factor to investment as well:

A stationary population with its larger proportion of old people may perhaps demand more personal services; and the composition of consumer demand will have an important influence on the quantity of capital required. (Hansen 1939, p. 7)

According to Hansen, an aging population also contributes to investment demand lagging behind the desired saving of households.

We can thus observe that Alvin Hansen expected highly developed economies to move toward secular stagnation due, above all, to diminishing investment opportunities.

It is important to stress here that Hansen did not see the decline into stagnation as inevitable. His objective was to identify the causes of a long-term weakening of growth, which he regarded as a realistic prospect, in order to be able to derive the necessary economic policy countermeasures. Paul Samuelson was Hansen's student at Harvard. In his obituary for Hansen, he addressed the still widespread misconception that Hansen, as a stagnation theorist, was automatically also a pessimist about growth:

Those who have not read Hansen carefully have often misinterpreted him. He was never pessimistic about the growth potential of the system. Hansen believed productivity trends were as good as ever, and perhaps even better. Hansen never believed we had to stagnate: he believed that any tendency toward ineffective demand could be offset by macroeconomic policy. (Samuelson 1976, p. 30)

In order to ward off the threat of stagnation, the state can respond by increasing public investment. Hansen-like Keynes-called for public investment in this context not only as a temporary stimulus, but as the necessary precondition for long-term growth with full employment. The state has to develop new and profitable investment opportunities, in order to compensate for deficient private

\footnotetext{
${ }^{16}$ Hansen's skepticism in this regard has clear parallels to the view that we put forward, in particular, in Sect. 6.1.8 that excessively high taxes have distorting effects that can reduce growth even further.
} 
investment. Hansen included investment in housing, transportation and resource development among such opportunities (Backhouse 2019, p. 453). According to Hansen, tax cuts could also be used to increase effective demand and stimulate investment. But he argued that the advantage of debt-financed public expenditure, as opposed to tax cuts, is that government bonds would represent stable and secure assets for private households, insurance companies and other financial institutions. In Hansen's view, it is also not a problem to place the additional bonds on the market, as they would meet with high demand in a prosperous society:

Moreover, at higher income levels the volume of savings increases and it is possible to sell more bonds to savings institutions, government trust funds, and the public. (Hansen 1941, p. 432)

For Hansen, however, it was not only important for purely economic reasons to counteract tendencies toward stagnation. Similar to how we argue especially in the second part of this book, Hansen also pointed out that the state has an important stabilizing function for the economy and that this is a key precondition for personal freedom and real democracy (cf. Mehrling 1997, p. 121).

Keynes's and Hansen's predictions of stagnation, which originated in the 1930s and 1940s, did not come true in the further course of the twentieth century. On the contrary, starting in the 1950s, there was a historically unprecedented boom, which persisted into the 1970s. Ever since, theories of stagnation have often been dismissed as refuted by these developments. Defenders of stagnation theories counter with the argument that after Keynes and Hansen, several special factors came into play, which suspended the tendencies to stagnation or more than compensated for them. These included, in particular, the phase of rebuilding after the Second World War. Keynes had already alluded to the effect of wars, and Hansen had made it clear that his expectation of stagnation would only be fulfilled in the absence of countervailing forces. For many economies, the process of catching-up to the USA also created a growth impetus. Since many of these effects have, in the meanwhile, run their course and significantly weaker growth can be observed in most OECD countries for several decades now, it could be useful to have another look at the growth determinants identified by Keynes and Hansen. Even if Hansen's prediction of stagnation has turned out to be false, the course of empirical economic development after the Second World War cannot serve as proof that the theory is invalid, since Hansen always stressed that stagnation only occurs if there are no counteracting forces. "In the aftermath of the Second World War, however, such counteracting forces did exist. Among them were especially a large backlog of demand in the first post-war years, massive government spending..., and the post-war baby boom" (Anselmann 2020, p. 57). But the effects of such forces are not apparent today. In the recent past, it is rather exactly the opposite that can be observed. 


\subsection{Larry Summers' Rediscovery of Alvin Hansen's Stagnation Thesis}

Already in 2010, Carl Christian von Weizsäcker first publicly called attention to the diverging of saving and investment that necessarily occurs under twenty-firstcentury conditions and to the role of the natural rate of interest (cf. the appendix to the present book). Unlike Larry Summers in his oft-cited speech at an IMF conference in 2013 (Summers 2013), von Weizsäcker did not make any reference to Alvin Hansen. Summers took up Hansen's concept of secular stagnation in his speech and connected it to the notion of the natural rate of interest, thus attracting greater public attention. He subsequently developed his reflections at somewhat greater length in several articles (Summers 2014, 2015). He himself describes his approach as the "new secular stagnation hypothesis." His point of departure is the natural rate of interest or a rate that he calls the "Full Employment Real Interest Rate" (FERIR). Summers is thus at least semantically close to the concept that already played a key role in Weizsäcker $(2010,2014)$ as an analytical tool for deriving a divergence of privately desired wealth and the demand for capital for investment purposes.

Summers wants to explain why, in light of a number of changed factors, there is no longer any FERIR coupled with low inflation. When Summers refers to "the interest rate" in his discussion, it is not always clear whether he referring to the money market rate, the natural rate of interest or some other interest rate. This does not make it particularly easy to follow the details of the arguments he puts forward for his hypothesis.

Summers holds the below factors responsible for tendencies toward stagnation and for a decline in the FERIR. He divides these factors into those that have a negative impact on the level of planned investment and those that have a positive impact on the level of planned saving (Summers 2014).

Among the factors dampening investment, he includes:

- demographic change,

- slower technological progress,

- a decline in the relative price of capital goods,

- a structural shift toward less capital-intensive sectors,

- less public investment and

- factors that are specifically connected to the major financial crisis of 2008-09.

According to Summers, factors that have increased households' propensity to save are:

- demographic change,

- an increasingly unequal distribution of income and

- factors specifically related to the financial crisis. 
In addition, global current account imbalances would have both a negative impact on investment and a positive effect on the propensity to save.

Secular stagnation does not have a single cause for Summers, but is rather the result of a chain of different structural shocks, which emerge in an unconnected or only loosely connected fashion. The mutually reinforcing impact of these shocks has lowered the "natural rate of interest" below zero. The factors mentioned by Summers include some of the causes of stagnation that Hansen identified. Unlike Hansen, however, Summers does not put the focus on the investment side. For Summers, the causes that have brought about an increased propensity to save appear to be at least as significant as the reasons for a general weakness in investment. But the crucial difference between Hansen and Summers is that the latter makes his secular stagnation hypothesis revolve around the natural rate of interest. Although Summers explicitly refers to Hansen, he provides no justification for why he places the natural rate of interest so much at the center of his analysis. This can best be explained by the fact that the natural rate plays an important role in Neo-Keynesianism (Woodford 2003) and Summers is, broadly speaking, a Neo-Keynesian. In this sense, his having recourse to the concept is understandable. But, given the other arguments that Summers uses to support what he himself calls his demand-oriented stagnation hypothesis, is it also necessary?

Various Post-Keynesians have criticized Summers for integrating the natural rate into his stagnation thesis and accused him of having "forgotten Keynes' message that interest rates may not solve demand shortage" (Palley 2016, p. 7; Hein 2016). If we consider in detail the reasons why, on Summers' account, stagnation comes about, we cannot rid ourselves of the impression that he could have also formulated his stagnation hypothesis without referring to the natural rate:

In contrast to Hansen, Summers's strong focus on the natural interest rate overshadows his otherwise Keynesian line of reasoning. One may say, in fact, that his secular stagnation theory could have done without the natural interest rate, as it can be maintained on purely Keynesian grounds. (Anselmann 2020, p. 86)

What Summers calls the "new secular stagnation hypothesis" can be described as new at most in the sense that he added a few more, specifically contemporary, factors to the factors that Hansen regarded as relevant. It is also new that Summers points to the danger of financial crises that could occur due to the formation of bubbles on asset markets, if central banks try to restore the balance between planned saving and investment by using monetary policy measures. But here too, it is not entirely clear why Summers assumes that the FERIR, which seems, after all, to be closely related to the concept of the natural rate, can be changed using monetary policy. ${ }^{17}$

\footnotetext{
${ }^{17}$ In the paper on secular stagnation that he jointly authored with Lukasz Rachel, Summers no longer uses the term "natural real interest rate" (Rachel and Summers 2019). Instead, already in the title, the authors speak of "neutral real interest rates." They thus suddenly use a term from Keynes's General Theory (Keynes 1936, p. 243). Just why the description and/or the concept of the interest rate has changed is not discussed in the paper.
} 
Although for Summers there is no single cause for the new stagnation tendencies, there are, in his view, two key countermeasures for neutralizing or at least mitigating their impact. On the one hand, he advocates a more progressive tax system and transfer payments to reverse the trend toward sharply rising income inequality in the USA in recent decades. On the other, he calls for an expansionary fiscal policy, which is to be used for financing public investment. In a later paper, however, Summers and his co-author Rachel are skeptical about the prospects for success of these measures (2019, p. 44): "There is no guarantee that deficits sufficient to maintain positive neutral real rates will be associated with sustainable debt trajectories." They here allude to the important question as to whether the long-term interest rate will be above or below the growth rate, which is of decisive significance for the sustainability of public debt (Blanchard 2019).

In principle, Rachel and Summers (2019) see three possible ways in which the economy could be stabilized in the long run, given the inequality between planned saving and planned investment:

Policymakers must, if they wish to avoid output being demand constrained, do some combination of accepting high and rising deficits and government debt levels, living with real interest rates very close to zero or negative, and finding structural policies that promote investment or reduce saving. (Rachel and Summers 2019, p. 44)

The authors suggest that these policy measures can be derived from their econometrically tested, theoretical model. But they have considerable doubts about their practical implementation: "We are not sure of their validity in practice" (ibid.). They explain their doubts by, among other things, a variety of considerations that are as much political as economic. Thus, unlike Alvin Hansen, who was an optimist about growth, it turns out that Larry Summers tends to be a pessimist about it.

Summers' contributions have triggered an intensive international debate about weaknesses in growth, stagnation and possible economic policy countermeasures. His causal analysis, like those of Keynes and Hansen, is clearly situated on the demand side. $^{18}$

\subsection{Keynes and the New Capital-Theoretical Approach}

In conclusion, we want to return to the questions posed at the outset of Sect. 7.3 on the causes for the divergence between planned saving and planned investment and the consequences to which it gives rise. Our aim here was essentially to show some key differences and similarities between the core hypotheses of this book and Keynesian stagnation theories. ${ }^{19}$ To this end, we presented the basic relationships in

\footnotetext{
${ }^{18}$ Demand-oriented stagnation hypotheses of this sort have been supplemented by significant supply-side considerations: like the arguments put forward, above all, by Gordon (2016). The latter contributions have likewise fueled the discussion about secular stagnation.

${ }^{19}$ On the relationship between the new capital-theoretical approach and Keynes, cf. Weizsäcker (2016).
} 
terms of flows, in order to make the connection to the preferred analysis in this book in terms of stocks. ${ }^{20}$

(1) We first addressed the causes that the different theories identify for the divergence between ex ante investment $I^{v}$ and ex ante saving $S^{\nu}$. In the previous chapters of this book, we argued in detail that the latter is primarily due to the rising desired saving of households. Private investment, on the other hand, does not increase commensurately in the long run, such that the Great Divergence between saving and investment comes about.

Keynesians look both at factors that influence saving and factors that affect investment. Nonetheless, the determinants of investment that lead to an imbalance between planned saving and planned investment are particularly frequently discussed by Keynes, Hansen and many of their followers. Whereas this book defends a specific variant of the savings glut hypothesis, ${ }^{21}$ Keynes and first generation Keynesians tend to make the "investment drought" hypothesis the focus. Most of the recent (neo-)Keynesian secular stagnation theories, by contrast, do not place any emphasis on one side or the other. ${ }^{22}$ They include all imaginable developments that could increase the propensity to save and reduce the propensity to invest in the long run. $^{23}$

In Keynesian theory, it is not scarcity of natural resources that leads to weak growth, as in the stagnation theorists of classical political economy or in some neoclassical approaches (Spahn 1986; Anselmann 2020). On the contrary, from a Keynesian perspective, stagnation gives rise to a prolonged underutilization of economic resources. Whereas Keynes only discussed the problem of underemployment in the General Theory, post-Keynesians include underutilization of capital stock in their analysis.

Keynesian theorists highlight the characteristic features of mature, highly developed economies that can give rise to stagnation. Alvin Hansen also speaks of stagnation being typical of a "high-savings economy." The Austrian post-Keynesian and Kaleckian, Josef Steindl, assumed that the trend toward oligopolization of highly developed economies brings about a reduction in investment (Backhouse and Boianovsky 2016). In such advanced and affluent societies, saving exceeds the

\footnotetext{
${ }^{20}$ Rachel and Summers $(2019$, p. 43) have also alluded to the equivalence between the two approaches: "We believe that these trends are best analyzed in terms of changes in saving and investment propensities or equivalently in terms of trends in desired wealth holdings by consumers and desired capital accumulation by producers."

${ }^{21}$ The expression "saving glut" was made famous by a speech by then Fed chair Bernanke (2005).

${ }^{22}$ This is especially clear in Summers' collection of possible factors presented above. Still other factors are adduced by the authors of the contributions to a collective volume edited by Teulings and Baldwin (2014).

23،"Three, Four... Many Secular Stagnations!"- this is how DeLong (2017) caricatures the wide variety of determinants that appear in the new debate on secular stagnation. He is also alluding to a certain arbitrariness in compiling the factors.
} 
amount that firms need to finance their investment. ${ }^{24}$ The fact that the planned saving of the private sector (households and firms) exceed the willingness to invest and borrow in an economy is thus "a phenomenon of prosperous, long-living societies," as Tichy (2016, p. 44) aptly observes.

(2) Secondly, we raised the issue of what happens when $S^{v} \neq I^{v}$. In orthodox neoclassical theory, the market mechanism ensures, primarily via the interest rate, that investment and saving balance and thus that a full-employment equilibrium is brought about. But there is no such automatic correction in either the new capital-theoretical approach or the Keynesian paradigm.

The reasons given to explain why the interest rate mechanism does not work are very different, but ultimately they lead to practically the same result. In the Keynesian analytical framework, household saving does not, in principle, free up funds for investment. An increase in saving merely redistributes already existing monetary resources: here, for example, from firms to households. The total liquid resources available are not changed, which is why interest rates will also not react to the increased saving of the household sector. In the new capital-theoretical approach for which we argue in this book, the private sector exhibits a structural excess of saving over investment even when the interest rate is zero. Since nominal interest rates cannot fall (much) below zero, a high level of employment can only be achieved by negative real interest rates or, in other words, inflation. Hence, whereas in the Keynesian paradigm, the interest rate cannot eliminate a disequilibrium between saving and investment for essential reasons, in the new capital-theoretical approach presented here, the interest rate de facto can no longer fulfill this function under the conditions prevailing in the twenty-first century.

The consequences that follow if fiscal policy fails to act are also described in an almost identical way. If there is a divergence between planned saving and investment - or, in other words, between desired wealth, on the one hand, and existing wealth, on the other-restoring the I-S equilibrium without additional public debt would mean an end to prosperity, price stability and full employment. The recessionary adjustment processes lead to what Keynes called an underemployment equilibrium: namely an economy that is characterized by persistent unemployment.

(3) Thirdly, we derived from this the question of whether government intervention is necessary, useful or harmful. In the orthodox view of a self-regulating market, the state's role is limited to just a few functions in the economy. Prolonged fiscal intervention is rejected on the grounds that productive private investment will be "crowded out" by public investment that tends to be less productive. This argument is based on the assumption of a fundamental scarcity of capital, requiring an efficient allocation of resources to maximize prosperity. The main focus of this book is the hypothesis that there is no longer any scarcity of capital under twenty-first-century conditions, but rather precisely the

\footnotetext{
${ }^{24}$ There is surprisingly little reference made to Steindl's stagnation theory in the current debate on secular stagnation. Hein (2016) and Anselmann (2020, pp. 195-239) represent recent exceptions.
} 
opposite. The key challenge now is to confront the savings glut resulting from private individuals' increasing desire to accumulate wealth. We have argued that the state is the only actor capable of absorbing these savings. Moreover, there are few other ways for the state to respond, so long as its citizens are not interested in using their longer lifespans to extend their active working lives to the same extent. This is what gives rise to the desire of citizens to accumulate more private wealth - or the necessity for them to do so - and the state has to respond by a commensurate increase of explicit and/or implicit public debt to ward off the threat of depression.

There is a necessity for government intervention also from the Keynesian perspective. Since the market mechanism and the interest rate are not able to prevent an underemployment equilibrium from coming into being, economic policy countermeasures are needed. In the view of most Keynesians, monetary policy cannot do what is required; hence, fiscal policy instruments have to be used.

Thus, the response to the phenomenon of a structural excess of saving or-the other side of the coin that a Keynesian would perhaps prefer to show-the lagging of aggregate effective demand behind aggregate supply largely coincides in both the Keynesian and the new capital-theoretical approaches: The state has to fill the gap by going into debt!

(4) The fourth question addressed the specific instruments that the state should use in reacting to a structural excess of private saving over private investment. In this book, we concentrate on presenting the finding that there is an excess of saving, on deriving and situating it theoretically, and on providing empirical support for it. In our opinion, the only possible response to the Great Divergence between saving and investment in the twenty-first century is an increase in public debt that fills the gap. Public dis-saving can be brought about either by generalized tax cuts or by increasing public spending. The use to which additional public revenue is put is a secondary matter in this connection and is not the subject of this book. At one place, we will discuss what seems to us to be one sensible use for these funds in the international context (cf. Chap. 11). But beyond that, we will not deal any further with the issue of the possible uses of additional public revenue. The second part of the book will, however, examine other economic policy consequences and options resulting from the Great Divergence.

There is a need for government intervention also from the Keynesian perspective. Depending on what is considered to be the main cause of the I-S disequilibrium and the resulting threat of stagnation, different measures are required. These range from economic policy measures for stimulating consumption or diminishing the propensity to save to subsidies for private investment and increased public investment. 
Almost all the possible public measures result in public debt also rising. Thus, in the Keynesian paradigm as well, the state is the key authority responsible for overcoming the threat of stagnation or at least mitigating tendencies toward it. An overview of the core Keynesian stagnation literature shows that the main aim in the Keynesian framework is to reduce the gap between planned investment and planned saving by way of public policy measures. In the Keynesian paradigm, the resulting public debt is more the consequence of government intervention, rather than, as in our case, the actual instrument for solving the problem.

To sum up, we can see that, despite all the differences in the theoretical framework and some differences in the details, there are a number of parallels between the Keynesian account of the causes and consequences of the structural divergence of planned private saving and investment, on the one hand, and, the new capital-theoretical conception, on the other. The key theoretical difference concerns the concept of the natural rate of interest, which does not even exist in the former and is analytically fundamental for the latter. But there are similarities especially in the view that, under twenty-first-century conditions, it is essential for the state to act to avoid instability and long-term underemployment. There is also large agreement on the important role that has to be played by public debt to close the gap between planned private saving and investment.

\section{References}

Anselmann, Christina. 2020. Secular Stagnation Theories. A Historical and Contemporary Analysis with a Focus on the Distribution of Income. Cham: Springer.

Backhouse, Roger E. 2019. Alvin Harvey Hansen. In The Elgar Companion to John Maynard Keynes, eds. Robert W. Dimand and Harald Hagemann, 451-455. Cheltenham: Edward Elgar.

Backhouse, Roger E. and Mauro Boianovsky. 2016. Secular stagnation: The history of a macroeconomic heresy. European Journal of the History of Economic Thought 23 (6): 946-970.

Bernanke, Ben. 2005. The global saving glut and the U.S. current account deficit. Speech 77. Washington (D.C.): Board of Governors of the Federal Reserve System.

Blanchard, Olivier. 2019. Public Debt and Low Interest Rates, AEA Presidential Lecture 2019. American Economic Review 109 (4): 1197-1229.

Blaug, Mark. 1962. Economic Theory in Retrospect. Homewood (IL): Richard D. Irwin.

Bofinger, Peter and Mathias Ries. 2017. Excess saving and low interest rates: Theory and Empirical Evidence. CEPR Discussion Paper 12111. London: Centre for Economic Policy Research. https://cepr.org/active/publications/discussion_papers/dp.php?dpno=12111. Accessed: 29 December 2018.

DeLong, J. Bradford. 2017. Three, Four... Many Secular Stagnations! https:/www.brad-forddelong.com/2017/01/three-four-many-secular-stagnations.html. Accessed: 28 October 2018.

Gordon, Robert J. 2016. The Rise and Fall of American Growth. The U.S. Standard of Living since the Civil War. Princeton (NJ): Princeton University Press. 
Hansen, Alvin H. 1936. Mr. Keynes on Underemployment Equilibrium. Journal of Political Economy 4 (5): 667-686.

Hansen, Alvin H. 1939. Economic Progress and Declining Population Growth. American Economic Review 29 (1): 1-15.

Hansen, Alvin H. 1941. Fiscal Policy and Business Cycles. London: Allen and Unwin.

Hansen, Alvin H. 1953. A Guide to Keynes. London: McGraw Hill.

Hansen, Alvin H. 1966. Stagnation and Under-Employment Equilibrium. Rostra Economica Amstelodamensia. 15 November 1966: 7-9.

Hein, Eckhard. 2016. Secular stagnation or stagnation policy? Steindl after Summers. PSL Quarterly Review 69 (276): 3-47.

Keynes, John Maynard. 1919 [1971]. The Economic Consequences of the Peace. In The Collected Writings of John Maynard Keynes, vol. 2: The Economic Consequences of the Peace, eds. Elizabeth Johnson and Donald Moggridge. London and Basingstoke: Macmillan.

Keynes, John Maynard. 1930 [1972]. Economic Possibilities for Our Grandchildren. In The Collected Writings of John Maynard Keynes, vol. 9: Essays in Persuasion, eds. Elizabeth Johnson and Donald Moggridge, 321-332. London and Basingstoke: Macmillan.

Keynes, John Maynard. 1936. The General Theory of Employment, Interest and Money. London: Macmillan.

Keynes, John Maynard. 1937. Some economic consequences of a declining population. The Eugenics Review 29 (1): 13-17. Reprinted 1973. In The Collected Writings of John Maynard Keynes, vol. 14: The General Theory and After (Part II: Defence and Development), eds. Elizabeth Johnson and Donald Moggridge, 124-133. London and Basingstoke: Macmillan.

Keynes, John Maynard. 1943 [1980]. The Long-Term Problem of Full Employment. In The Collected Writings of John Maynard Keynes, vol. XXVII: Activities 1940-1946. Shaping the Post-War World: Employment and Commodities, eds. Elizabeth Johnson and Donald Moggridge, 320-325. London and Basingstoke: Macmillan.

Kurz, Heinz D. 2017. Economic Thought: A Brief History. New York: Columbia University Press.

Meade, James. 1975. The Keynesian Revolution. In Essays on John Maynard Keynes, ed. Milo Keynes, 82-88. New York (NY): Cambridge University Press.

Mehrling, Perry G. 1997. The Money Interest and the Public Interest: American Monetary Thought, 1920-1970. Cambridge (MA): Harvard University Press.

Palley, Thomas I. 2016. Why Negative Interest Rate Policy (NIRP) Is Ineffective And Dangerous. Real-World Economics Review 76. http://www.paecon.net/PAEReview/issue76/Palley76.pdf. Accessed: 31 October 2018.

Palley, Thomas I. 2019. The fallacy of the natural rate of interest and zero lower bound economics: why negative interest rates may not remedy Keynesian unemployment. Review of Keynesian Economics 7 (2): 151-170.

Rachel, Lukasz and Lawrence H. Summers. 2019. On Falling Neutral Real Rates, Fiscal Policy, and the Risk of Secular Stagnation. Brookings Papers on Economic Activity March 4: 1-66.

Samuelson, Paul A. 1976. Alvin Hansen as a Creative Economic Theorist. Quarterly Journal of Economics 90 (1): 24-31.

Schumpeter, Joseph A. 1954. History of Economic Analysis. New York (NY): Oxford University Press.

Spahn, Heinz-Peter. 1986. Stagnation in der Geldwirtschaft. Dogmengeschichte, Theorie und Politik aus keynesianischer Sicht. Frankfurt am Main and New York (NY): Campus.

Summers, Lawrence H. 2013. Speech at IMF Fourteenth Annual Research Conference in Honor of Stanley Fischer. 8 November 2013. Washington (D.C.): International Monetary Fund.

Summers, Lawrence H. 2014. US Economic Prospects: Secular Stagnation, Hysteresis, and the Zero Lower Bound. Business Economics 49: 65-73.

Summers, Lawrence H. 2015. Demand Side Secular Stagnation. American Economic Review: Papers and Proceedings 105 (5): 60-65. 
Teulings, Coen and Richard Baldwin (eds.). 2014. Secular Stagnation: Facts, Causes and Cures. London: CEPR Press. http://www.voxeu.org/sites/default/files/Vox_secular_stagnation.pdf. Accessed: 6 December 2014.

Tichy, Gunther. 2016. Vom Kapitalmangel zum Savings Glut: Ein Phänomen der Wohlstandsgesellschaft. In Keynes, Schumpeter und die Zukunft der entwickelten kapitalistischen Volkswirtschaften, eds. Harald Hagemann and Jürgen Kromphardt, Schriften der Keynes Gesellschaft, vol. 9, 33-68. Marburg: Metropolis-Verlag.

Weizsäcker, Carl Christian von. 2010. Das Janusgesicht der Staatsschulden. Frankfurter Allgemeine Zeitung. 4 June 2010: 12 (published in the appendix to this book as "The Two Faces of Public Debt").

Weizsäcker, Carl Christian von. 2014. Public Debt and Price Stability. German Economic Review 15 (1): 42-61.

Weizsäcker, Carl Christian von. 2016. Keynes und das Ende der Kapitalknappheit. In Keynes, Schumpeter und die Zukunft der entwickelten kapitalistischen Volkswirtschaften, eds. Harald Hagemann and Jürgen Kromphardt, Schriften der Keynes Gesellschaft, vol. 9, 21-31. Marburg: Metropolis-Verlag.

Wicksell, Knut. 1936 [1898]. Interest and Prices: A Study of the Causes Regulating the Value of Money, trans. R. F. Kahn. London: Macmillan.

Woodford, Michael. 2003. Interest and Prices: Foundations of a Theory of Monetary Policy. Princeton (NJ): Princeton University Press.

Open Access This chapter is licensed under the terms of the Creative Commons Attribution 4.0 International License (http://creativecommons.org/licenses/by/4.0/), which permits use, sharing, adaptation, distribution and reproduction in any medium or format, as long as you give appropriate credit to the original author(s) and the source, provide a link to the Creative Commons license and indicate if changes were made.

The images or other third party material in this chapter are included in the chapter's Creative Commons license, unless indicated otherwise in a credit line to the material. If material is not included in the chapter's Creative Commons license and your intended use is not permitted by statutory regulation or exceeds the permitted use, you will need to obtain permission directly from the copyright holder. 